\title{
ANALISIS PENGARUH JERAMI PADI SEBAGAI BAHAN PENGISI BATAKO DENGAN PEREKAT LEM KAYU JENIS PVAC DITINJAU DARI BERAT ISI, KUAT TEKAN DAN DAYA SERAP AIR
}

\author{
Robi Fuadi ${ }^{1}$, Sri Sumarni ${ }^{2}$, Sukatiman ${ }^{3}$ \\ email: fuadr.5061@gmail.com
}

\begin{abstract}
Abstrak
Tujuan penelitian adalah, (1) mengetahui adalah pengaruh penambahan variasi jerami padi dengan perekat lem kayu jenis PVAc sebagai bahan isi batako terhadap berat isi batako, kuat tekan dan daya serap air (absorption), (2) mengetahui berat isi batako yang dihasilkan termasuk beton ringan, (3) Untuk mengetahui variasi dimensi jerami padi yang optimal yang menghasilkan batako dengan kuat tekan maksimal dan sesuai standar yang berlaku, (4) Untuk mengetahui daya serap air batako yang dihasilkan sesuai standar daya serap air bata beton ringan untuk pasangan dinding.Penelitian ini menggunakan metode kuantitatif eksperimen dan teknik analisa data menggunakan analisis regresi. Variabel yang mempengaruhi dalam penelitian adalah (1) variabel terikat: berat isi, kuat tekan dan daya serap air batako, (2) varibel bebas: penambahan jerami padi dalam bentuk balok dengan dimensi jerami (lebar : tinggi : panjang); $5 \mathrm{~cm}: 5 \mathrm{~cm}: 25 \mathrm{~cm}, 5 \mathrm{~cm}: 10 \mathrm{~cm}: 25 \mathrm{~cm}$, $5 \mathrm{~cm}: 15 \mathrm{~cm}: 25 \mathrm{~cm}, 5 \mathrm{~cm}: 5 \mathrm{~cm}: 30 \mathrm{~cm}, 5 \mathrm{~cm}: 10 \mathrm{~cm}: 30 \mathrm{~cm}, 5 \mathrm{~cm}: 15 \mathrm{~cm}: 30 \mathrm{~cm}$. Berdasarkan hasil penelitian disimpulkan bahwa, (1) penambahan jerami padi pada batako berpengaruh terhadap berat isi batako, kuat tekan dan daya serap air batako (absorption) (2) hasil pengujian berat isi batako menunjukkan batako dengan penambahan jerami padi dalam bentuk balok termasuk kategori beton ringan sesuai SNI 03-2834-2000, yaitu dengan hasil antara $1000 \mathrm{~kg} / \mathrm{m}^{3}-2200 \mathrm{~kg} / \mathrm{m}^{3}$, (3) variasi optimal jerami padi dalam bentuk balok sebagai bahan pengisi batako yang menghasilkan kuat tekan batako maksimal sesuai SNI 03-0349-1989 terdapat pada pada variasi jerami dengan ukuran $5 \mathrm{~cm}$ : $5 \mathrm{~cm}: 25$ $\mathrm{cm}$ yaitu sebesar $25,64 \mathrm{Kg} / \mathrm{cm}^{2}$. (4) hasil pengujian daya serap air (absorption) batako dengan penambahan jerami padi dalam bentuk balok masih di bawah syarat penyerapan air rata-rata maksimal batako sesuai SNI 03-349-1989 yaitu < 25\% termasuk dalam tingkat mutu bata beton pejal I.
\end{abstract}

Kata Kunci: batako, jerami, berat isi, kuat tekan, daya serap air.

\footnotetext{
${ }^{1}$ Mahasiswa Program Studi Pendidikan Teknik Bangunan Universitas Sebelas Maret

${ }^{2}$ Pengajar Program Studi Pendidikan Teknik Bangunan Universitas Sebelas Maret
} 


\title{
ANALYSIS OF THE EFFECTS OF STRAW AS FILLER MATERIALS FOR CONCRETE BLOCK WITH ADHESIVE PVAC GLUE FROM BULK DENSITY, COMPRESIVE STRENGTH AND WATER ABSORPTION
}

\author{
Robi Fuadi ${ }^{1}$, Sri Sumarni ${ }^{2}$, Sukatiman ${ }^{3}$ \\ Email: fuadr.5061@gmail.com
}

\begin{abstract}
The aims of this study: (1) to know the influence of straw addition combined with the PVAc adhesive glue material as material of concrete block contents to the bulk density, compressive strength and absorption of the concrete block, (2) to know concrete block bulk density which was resulted from the process including light concrete block (3) To find out the optimum variation of straw dimension that produces concrete block with maximum compressive strength and have applicable standard, (4) To know the absorption of concrete block water produced according to absorption standard of light concrete block for wall. This study used quantitative method of experiment and regression analysis for data analysis technique. Variables which influenced this study were (1) Dependent variable, such as bulk density, compressive strength and concrete block water absorption (2) Independent variable, such as straw addition in the from of beam with dimension of straw (widht : height : length); $5 \mathrm{~cm}: 5 \mathrm{~cm}: 25 \mathrm{~cm} ; 5 \mathrm{~cm}: 10 \mathrm{~cm}: 25 \mathrm{~cm} ; 5 \mathrm{~cm}: 15 \mathrm{~cm}: 25 \mathrm{~cm}$; $5 \mathrm{~cm}: 5 \mathrm{~cm}: 30 \mathrm{~cm} ; 5 \mathrm{~cm}: 10 \mathrm{~cm}: 30 \mathrm{~cm} ; 5 \mathrm{~cm}: 15 \mathrm{~cm}: 30 \mathrm{~cm}$. Based on the result of the study, it was concluded that (1) Addition of straw on the concrete block has a effect on the weight, compressive strength dan absorption of the concrete, (2) The results of the bulk density test of the contents of the concrete block show the concrete block with the addition of straw in the form of beam including the lightweight concrete category according to Indonesia Standart 03-2834-2000, that is between $1000 \mathrm{~kg} / \mathrm{m}^{3}-2200 \mathrm{~kg} / \mathrm{m}^{3}$, (3) The optimal variation of straw in the shape of the beam as a concrete block material that produces the maximum strength of concrete block press according to Indonesia Standart 03-0349-1989 is on the variation of straw with the size $5 \mathrm{~cm}: 5 \mathrm{~cm}: 25 \mathrm{~cm}$ that is equal to $25.64 \mathrm{Kg} / \mathrm{cm}^{2}$, (4) The result of concrete block water absorption with addition of straw in the form of beam is still below the maximum water absorption requirement of the bracket in accordance with Indonesia Standart 03-349-1989 i e <25\% included in the level of solid concrete block quality I.
\end{abstract}

Keyword: concrete block, straw, bulk density, compressive strength, absorption.

\footnotetext{
${ }^{1}$ Student Of Civil Enginering Education On Sebelas Maret University

${ }^{2}$ Lecture Of Civil Enginering Education On Sebelas Maret University
} 


\section{PENDAHULUAN}

Batako pada saat ini semakin populer digunakan sebagai pengganti batu bata merah. Hal ini disebabkan karena batako dinilai lebih cepat dalam pembuatan maupun pengerjaannya untuk pasang dinding. Dalam pembuatan batako tidak memerlukan proses pembakaran seperti pembuatan batu bata merah. Maka secara tidak langsung kebutuhan batako akan meningkat sebagai pengganti penggunaan batu bata merah (Anggakusuma, 2014).

Eksploitasi tanah liat sebagai bahan utama pembuatan batu bata merah juga akan berdampak pada kerusakan lingkungan. Oleh karena itu perlu adanya inovasi untuk menciptakan bahan bangunan yang lebih ramah lingkungan. Salah satunya adalah dengan beralih ke bata beton atau batako dengan bahan tambah jerami padi yaitu batang padi setelah pasca panen (lihat gambar 1). Dengan optimalisasi pemanfaatan limbah pertanian yang berupa jerami padi sebagai bahan pengisi batako ini diharapkan akan dapat mengurangi kerusakan lingkungan akibat eksploitasi tanah liat sebagai bahan utama pembuatan batu bata dan juga mengoptimalkan pemanfaatan limbah jerami padi pada industri konstruksi.

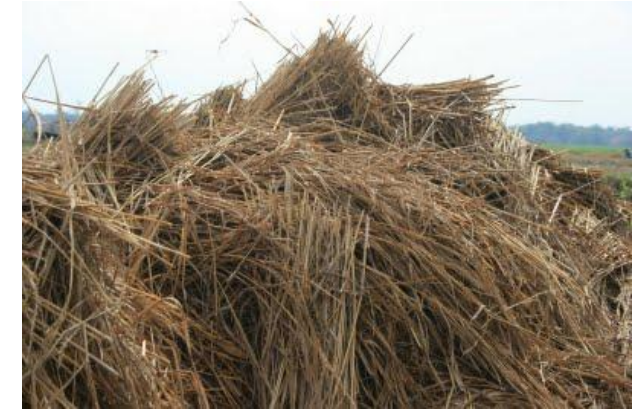

Gambar 1. Jerami Padi Pascapanen

Beberapa negara juga sudah melakukan inovasi penambahan jarami pada bahan bangunan. Dalam penelitian yang dilakukan oleh Wei Liu, Wie Xi dan Yilu Zhang (2014). Pemanfaatan jerami menjadi bahan campuran beton menunjukkan beton dengan campuran jerami kuat tekan dan modulus elastisitas yang hampir sama dengan beton yang tidak dicampuri dengan jerami.

Penelitian yang dilakukan Wisnu (2008) juga menunjukkan ada pengaruh positif penambahan jerami padi terhadap kuat tekan batako. Pada hasil uji daya serap air (absorbtion) menunjukkan bahwa semakin besar dimensi jerami padi, maka semakin besar pula daya serap air (absorbtion) nilai daya serap air maksimal terdapat pada dimensi jerami (lebar: tinggi: panjang) $5 \mathrm{~cm}: 15 \mathrm{~cm}$ : $35 \mathrm{~cm}$ dengan nilai $8,23 \%$. Namun pada hasil uji kuat tekan, kuat tekan yang diperoleh dari analisis regresi Curve Estimation model Qubic menunjukkan nilai kuat tekan batako maksimal adalah 1,507 Mpa pada dimensi jerami $5 \mathrm{~cm}$ : $5 \mathrm{~cm}$ : $25 \mathrm{~cm}$. Hal ini belum memenuhi kuat tekan minimal bata beton sebagai pasangan batu sesuai SNI 03-0349-1989.

Sesuai SNI 03-0349-1989 bata beton untuk pasangan dinding harus memenuhi syarat fisis kuat tekan dan daya serap air bata beton sesuai tabel 1 dan 2 di bawah ini,

Tabel 1. Persyaratan kuat tekan minimum batako pejal sebagai bahan bangunan

\begin{tabular}{lcccccc}
\hline \multirow{2}{*}{ No } & Syarat Fisis & Satuan & \multicolumn{5}{c}{ Tingkat Mutu Bata Beton Pejal } \\
\cline { 3 - 7 } & & I & II & III & IV \\
\hline 1 & $\begin{array}{c}\text { Kuat Tekan Bruto } \\
\text { (rata-rata bruto) }\end{array}$ & $\mathrm{Kg} / \mathrm{cm}^{2}$ & 100 & 70 & 40 & 25 \\
\hline 2 & $\begin{array}{c}\text { Kuat Tekan Bruto masing } \\
\text { masing benda uji(minimum) }\end{array}$ & $\mathrm{Kg} / \mathrm{cm}^{2}$ & 90 & 65 & 35 & 21 \\
\hline
\end{tabular}

Tabel 2. Persyaratan penyerapan air minimum batako pejal

\begin{tabular}{lcccccc}
\hline \multirow{2}{*}{ No } & Syarat Fisis & Satuan & \multicolumn{4}{c}{ Tingkat Mutu Bata Beton Pejal } \\
\cline { 3 - 7 } & & & I & II & III & IV \\
\hline 1 & $\begin{array}{c}\text { Penyerapan air rata-rata } \\
\text { (minimum) }\end{array}$ & $\%$ & 25 & 35 & - & - \\
\hline
\end{tabular}


Bata beton untuk pasangan dinding juga harus memenuhi syarat berat isi beton sesuai pemakaian yaitu beton ringan (Wisnu, 2008). Menurut SNI 03-2834-2000 berat isi beton sesuai pemakaian dapat dibagai sesuai dengan tabel 3 di bawah ini

Tabel 3. Berat isi beton sesuai pemakaian

\begin{tabular}{|c|c|c|}
\hline Jenis Beton & Berat Isi & Pemakaian \\
\hline Beton Sangat Ringan & $<1000$ & Non Struktur \\
\hline Beton Ringan & $1000-2100$ & Struktur Ringan \\
\hline Beton Normal & $2200-2500$ & Struktur \\
\hline Beton Berat & $>2500$ & Perisasi Sinar X \\
\hline
\end{tabular}

Jerami merupakan salah satu tanaman yang mengandung serat dan telah digunakan produksi pulp dan kertas. Selain itu, pemanfaatan jerami sebagai bahan bangunan yaitu digunakan sebagai bahan penutup atap pada tempat peristirahatan atau cottage. Dengan melimpahnya jerami sebagai limbah pertanian di Indonesia yang bisa mencapai 12-15 ton setiap hektar pada masa panen, atau 4-5 ton bahan kering tergantung pada lokasi dan jenis varietas tanaman yang digunakan. Biasanya di daerah-daerah Jawa Tengah, Yogyakarta dan Jawa Timur jerami hanya digunakan untuk pakan ternak seperti sapi atau kerbau (Wijanarko, 2008). Dengan ketersediaan sebanyak itu sangat memungkinkan adanya inovasi baru untuk memanfaatkannya sebagai bahan material konstruksi bangunan, terutama pada batako.

Jerami sebagai bahan pengisi batako dibuat dalam bentuk balok seperti pada gambar 2 dengan dimensi tertentu. Proses pembuatan jerami padi dalam bentuk balok digunakan bahan berupa lem kayu jenis PVAc dan alat cetak batako. Jerami padi yang telah kering tungku ditambahkan lem kayu PVAc kemudian di masukan ke dalam alat cetak batako, lalu dipres dengan delapan kali putaran. Lakukan proses tersebut sampai cetakan batako terisi penuh, kemudian potong sesuai variasi dimensi.

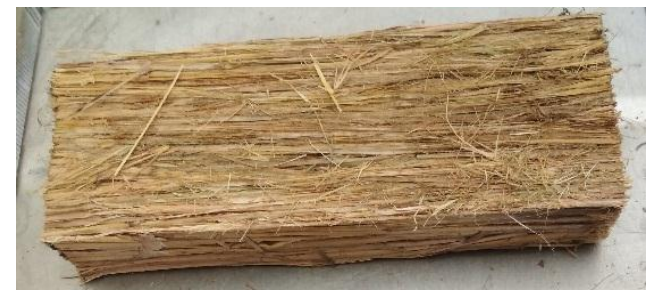

Gambar 2. Jerami dalam Bentuk Balok

Penggunaan lem kayu jenis PVAc pada jerami padi dilakukan untuk membuat kekakuan hasil pada cetakan jerami padi. Sehingga menambah kekuatan ikat antar jerami padi yang diharapkan dapat menambah kuat tekan pada batako. Lem kayu jenis PVAc mudah dijumpai karena dijual di tokotoko bahan bangunan dan sering dipakai pada industri kayu.

Dalam meningkatkan kuat tekan batako dan mempermudah proses pengerjaan pembuatan batako perlu adanya bahan tambah yang dicampurkan kedalam mortar. Salah satunya adalah tetes tebu atau molase. Tetes tebu atau molase adalah salah satu limbah pabrik gula. Molase merupakan sisa dari hasil kristalisasi gula yang berulang-ulang sehingga tidak memungkinkan lagi unuk diproses menjadi gula. Molase masih mengandung $50 \%$ sampai $60 \%$ gula. Prima dkk (2013) mengatakan penambahan penggunaan molase pada campuran beton dapat meningkatkan nilai slump serta memperlambat waktu ikat awal dan waktu ikat akhir pada setiap penambahan variasi.

\section{METODE PENELITIAN}

Jenis penelitian ini merupakan penelitian kuantitatif eksperimen yaitu dengan mengambil gambaran mengenai pengaruh penambahan variasi dimensi jerami padi dalam bentuk balok pada batako terhadap berat isi kuat tekan dan 
daya serap air batako. Penelitian ini dilakukan di satu tempat, yaitu di Laboratorium PTB FKIP Universitas Sebelas Maret Surakaarta.

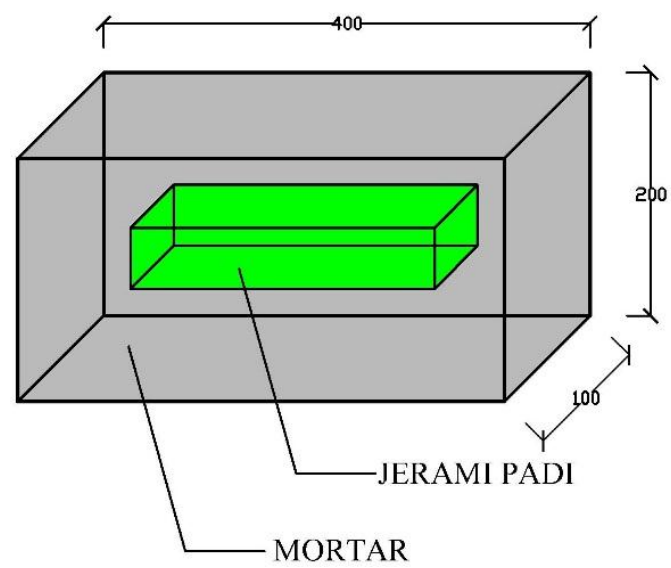

Gambar 3. Desain Rencana Batako Isi Jerami

Populasi pada penelitian ini adalah batako tipe $\mathrm{E}$ dengan ukuran (lebar: tinggi: panjang) $10 \mathrm{~cm}: 20 \mathrm{~cm}$ : $40 \mathrm{~cm}$. Batako ditambah dengan jerami padi dalam bentuk balok seperti pada gambar 3. Jumlah populasi dalam penelitian ini sebanyak 80 buah benda uji, untuk sampel yang digunakan dalam penelitian ini adalah 80 buah benda uji. Dalam penelitian ini terdapat 8 variasi sampel yang digunakan untuk pengujian berat isi, kuat tekan dan daya serap air, yang terdiri dari batako tanpa jerami dan tanpa molase, batako tanpa jerami dengan molase dan batako dengan isi jerami dalam bentuk balok dengan dimensi (lebar: tinggi: panjang) $5 \mathrm{~cm}$ : $5 \mathrm{~cm}: 25 \mathrm{~cm}, 5 \mathrm{~cm}: 10 \mathrm{~cm}: 25 \mathrm{~cm}, 5 \mathrm{~cm}$ : $15 \mathrm{~cm}: 25 \mathrm{~cm}, 5 \mathrm{~cm}: 5 \mathrm{~cm}: 30 \mathrm{~cm}, 5 \mathrm{~cm}$ : $10 \mathrm{~cm}: 30 \mathrm{~cm}, 5 \mathrm{~cm}: 15 \mathrm{~cm}: 30 \mathrm{~cm}$.

Setiap variasi terdapat 5 sampel benda uji. Metode pencapuran volume 1 semen (Pc): 5 pasir (Ps), dengan nilai fas 0,5 dan penambahan tetes tebu (molase) sebesar $0,25 \%$ dari semen. Penggunaan $0,25 \%$ molase dari semen ditentukan berdasarkan peneltian yang telah dilakukan oleh prima dkk (2013), dimana penambahan $0,25 \%$ pada beton mempunya nilai yang optimal pada kuat tekan beton. Teknik analisa data yang digunakan adalah analisis regresi.

\section{HASIL DAN PEMBAHASAN 1. SNI yang Digunakan}

Dalam penelitian ini dilakukan pengujian bahan agregat halus (pasir) sesuai standar yang berlaku. Pengujian dilakukan untuk memastikan agregat harus sesuai standar dan layak untuk digunakan sebagai bahan bangunan. Berikut standar yang digunakan dalam pengujian agregat halus,

Tabel 4. SNI Pengujian Bahan

\begin{tabular}{ll}
\hline \multicolumn{1}{c}{ Jenis Pengujian } & \multicolumn{1}{c}{$\begin{array}{c}\text { Standar yang } \\
\text { Digunakan }\end{array}$} \\
\hline Kadar Lumpur & $\begin{array}{l}\text { PBBI (Peraturan } \\
\text { Beton Bertulang } \\
\text { Indonesia) 1971 }\end{array}$ \\
\hline $\begin{array}{l}\text { Kandungan zat } \\
\text { organic }\end{array}$ & $\begin{array}{l}\text { PBBI (Peraturan } \\
\text { Beton Bertulang } \\
\text { Indonesia) 1971 }\end{array}$ \\
\hline Kadar air & SNI-1970- 2008 \\
\hline $\begin{array}{l}\text { Bulk Spesific } \\
\text { Grafity (SSD) }\end{array}$ & SNI 1970- 2008 \\
\hline Absorbtion & SNI 1970- 2008 \\
\hline Pengujian Gradasi & SNI 03-1968-1990 \\
\hline
\end{tabular}

\section{Hasil Pengujian Agregat}

Sebelum dilakukan pengujian agregat halus lebih lanjut, agregat terebih dahulu diuji kadar lumpur untuk mengetahui nilai kadar lumpur yang terkandung. Berikut disajikan hasil pengujian kadar lumpur agregat halus (pasir) pada tabel 5 di bawah ini,

Tabel 5. Hasil Pengujian Agregat

\begin{tabular}{lccc}
\hline \multicolumn{4}{c}{ Hasil Pengujian Agregat Halus } \\
\hline $\begin{array}{c}\text { Jenis } \\
\text { Pengujian }\end{array}$ & Hasil & Standar & Keterangan \\
\hline $\begin{array}{l}\text { Kadar } \\
\text { lumpur } \\
\text { sebelum } \\
\text { dicuci }\end{array}$ & 31,3 & $<5 \%$ & $\begin{array}{c}\text { Tidak } \\
\text { memenuhi } \\
\text { standar }\end{array}$ \\
\hline
\end{tabular}

Pada hasil pengujian kadar lumpur seperti tabel 5 diketahui agregat halus mempunyai kadar lumpur sebesar 
$31,3 \%$, nilai tersebut tidak sesuai standar yang berlaku yaitu < 5\%. Hal ini membuat agregat halus harus dicuci terlebih dahulu untuk menghilangkan kadar lumpur yang terkandung dalam agregat tersebut sebelum diuji pada tahap selanjutnya dan digunakan dalam penelitian.

Tabel 6. Hasil Pengujian Agregat Halus

\begin{tabular}{|c|c|c|c|}
\hline $\begin{array}{c}\text { Jenis } \\
\text { Pengujian }\end{array}$ & Hasil & Standar & Keterangan \\
\hline $\begin{array}{l}\text { Kadar } \\
\text { lumpur } \\
\text { setelah } \\
\text { dicuci }\end{array}$ & $1,17 \%$ & $<5 \%$ & $\begin{array}{l}\text { Memenuhi } \\
\text { standar }\end{array}$ \\
\hline $\begin{array}{l}\text { Kandungan } \\
\text { zat organik }\end{array}$ & $\begin{array}{c}\text { Kunin } \\
\mathrm{g} \\
\text { muda }\end{array}$ & $0-10$ & $\begin{array}{l}\text { Memenuhi } \\
\text { standar }\end{array}$ \\
\hline Kadar air & $3,90 \%$ & $1-3 \%$ & $\begin{array}{c}\text { Tidak } \\
\text { memenuhi } \\
\text { standar }\end{array}$ \\
\hline $\begin{array}{l}\text { Bulk Spesific } \\
\text { Grafity } \\
\text { (SSD) }\end{array}$ & $\begin{array}{c}2,54 \\
\mathrm{~kg} / \mathrm{m}^{3}\end{array}$ & $\begin{array}{c}2,5- \\
2,7\end{array}$ & $\begin{array}{l}\text { Memenuhi } \\
\text { syarat }\end{array}$ \\
\hline Absorbtion & $0,72 \%$ & - & - \\
\hline $\begin{array}{l}\text { Modulus } \\
\text { kehalusan } \\
\text { butiran }\end{array}$ & 3,56 & $\begin{array}{c}1,5- \\
3,8\end{array}$ & $\begin{array}{l}\text { Memenuhi } \\
\text { standar }\end{array}$ \\
\hline
\end{tabular}

Pada hasil pengujian agregat halus sesuai dengan tabel 6 , dapat dilihat bahwa hanya ada satu hasil pengujian yang tidak memenuhi standar yaitu pada pengujian kadar air. Hasil pengujian kadar air dengan nilai 3,90\% masih terlalu tinggi (standar 1-3\%) oleh karena itu pada saat pelaksaan pembuatan mortar batako harus diperhatikan penambahan air agar mortar tidak terlalu banyak air dan membuat menguarngi mutu batako.

\section{Berat Isi Batako}

Berdasarkan SNI 03-2834-2000 (lihat tabel 3) berat isi beton ringan berkisar antara $1000 \mathrm{~kg} / \mathrm{m}^{3}$ sampai $2100 \mathrm{~kg} / \mathrm{m}^{3}$. Dapat di lihat pada gambar 4 bahwa berat isi pada semuad variasi jerami masih masuk dalam kategori beton ringan karena masih diantara $1000 \mathrm{~kg} / \mathrm{m}^{3}$ sampai $2100 \mathrm{~kg} / \mathrm{m}^{3}$. Sehingga dalam penelitian ini batako dengan penambahan jerami termasuk dalam kategori beton ringan.

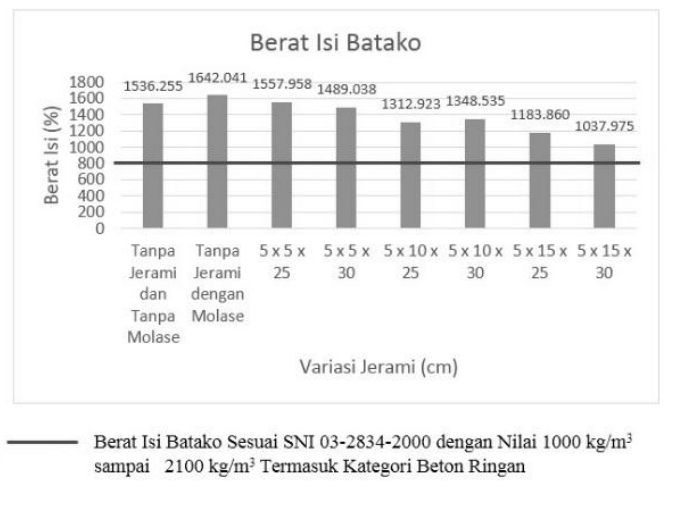

Gambar 4. Grafik Hasil Pemeriksaan Berat Isi Batako

Batako yang mempunyai variasi jerami lebih kecil dengan ukuran (lebar: tinggi: panjang) $5 \mathrm{~cm}: 5 \mathrm{~cm}$ : $25 \mathrm{~cm}$ mempunyai berat isi lebih besar dibanding dengan dengan batako yang mempunyai variasi jerami dengan ukuran lebih besar. Dimensi jerami dalam bentuk balok yang lebih besar akan mengurangi volume mortar sehingga membuat berat isi batako akan semakin lebih ringan. Hal ini diperkuat dengan hasil penelitian Wijanarko (2008) yang menunjukkan bahwa penambahan jerami dalam bentuk balok sebagai bahan pengisi batako berpengaruh kuat terhadap berat isi batako. Hal ini terjadi karena jerami padi dalam bentuk balok menyubsidi volume mortar pada batako. Berat isi dari batako tersebut menjadi lebih ringan. Sehingga penambahan jerami padi dalam bentuk balok pada batako berpengaruh positif pada berat isi batako. 


\section{Kuat Tekan Batako}

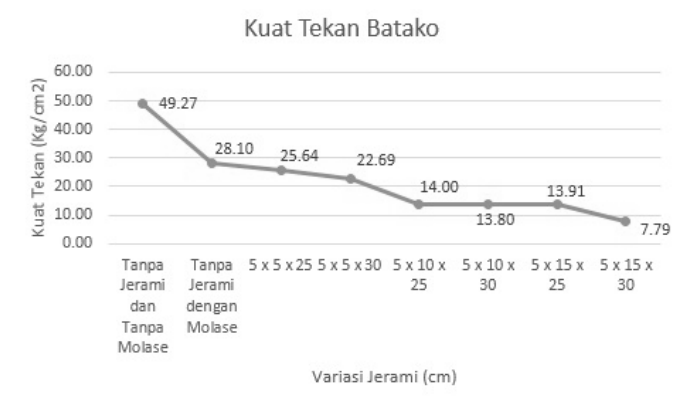

Gambar 5. Grafik Hasil Pengujian Kuat Tekan Batako

Berdasarkan hasil pengujian kuat tekan batako pada gambar 5 di atas terlihat batako normal tanpa penambahan jerami dan molase mempunyai kuat tekan sangat tinggi yaitu dengan nilai 49,27 Kg/cm2 . Sementara batako dengan penambahan molase tanpa penambahan jerami mempunyai kuat tekan sebesar 28,10 $\mathrm{Kg} / \mathrm{cm}^{2}$. Penambahan molase sebesar $0,25 \%$ dari semen menurunkan kuat tekan dari batako.

Kuat tekan batako dengan penambahan jerami dan molase paling besar yaitu pada batako dengan variasi jerami (lebar: tinggi: panjang) $5 \mathrm{~cm}: \quad 5 \mathrm{~cm}: \quad 25 \mathrm{~cm}$ sebesar 25,64 $\mathrm{Kg} / \mathrm{cm}^{2}$. Kemudian pada penambahan variasi jerami padi dengan ukuran $5 \mathrm{~cm}: 5 \mathrm{~cm}: 30 \mathrm{~cm}$ dan $5 \mathrm{~cm}: 10 \mathrm{~cm}$ : $25 \mathrm{~cm}$ mengalami penurunan sebesar $22,69 \mathrm{Kg} / \mathrm{cm} 2$ dan $14,00 \mathrm{Kg} / \mathrm{cm}^{2}$. Penurunan kuat tekan juga terjadi pada batako dengan vasriasi jerami $5 \mathrm{~cm}$ : $10 \mathrm{~cm}$ : $30 \mathrm{~cm}$ yaitu sebesar 13,80 $\mathrm{Kg} / \mathrm{cm}^{2}$. Sementara pada variasi $5 \mathrm{~cm}$ : $15 \mathrm{~cm}: 25 \mathrm{~cm}$ mengalami kenaikan cukup kecil yaitu sebesar 13,91 $\mathrm{Kg} / \mathrm{cm}^{2}$. Kuat tekan batako dengan penambahan jerami terkecil terdapat pada variasi jerami $5 \mathrm{~cm}: 15 \mathrm{~cm}: 30 \mathrm{~cm}$ yaitu sebesar $7,79 \mathrm{Kg} / \mathrm{cm}^{2}$.

Pada umumnya dari data di atas menggambarkan bahwa kuat tekan dan ukuran volume atau variasi jerami pada batako berbanding terbalik. Semakin besar volume atau dimensi variasi jerami pada batako maka semakin kecil nilai kuat tekan batako.

Berdasarkan hasil pengujian kuat tekan batako menunjukkan bahwa batako dengan penambahan jerami dalam bentuk balok yang memenuhi standar mutu kuat tekan sesuai SNI 03-0349-1989 hanya pada variasi jerami $5 \mathrm{~cm}: 5 \mathrm{~cm}: 25 \mathrm{~cm}$, sementara kuat tekan pada variasi lainnya belum memenuhi standar. Hal ini disebabkan dalam pencetakan batako mengalami kesulitan, karena semakin besar dimensi variasi jerami maka semakin sulit pula dalam mencetak batako. Daya rekat campuran batako menjadi berkurang, karena jerami kering mempunyai sifat menyerap air. Sehingga dalam pelepasan cetakan seringnya rubuh pada bagian tepi batako dan gagal untuk mencapai bentuk batako sesuai dengan cetakan, sehingga pencetakan ulang harus dilakukan. Dengan permasalahan tersebut, hasil dari uji kuat tekan didapatkan hasil yang variatif.

Hasil penelitian ini juga diperkuat dengan hasil penelitian pemanfaatan jerami menjadi bahan campuran beton juga pernah dilakukan oleh Wei Liu, Wei Xi dan Yilu Zhang di Jilin Jianzhu Univercity, Changchun, China. Dalam jurnalnya yang berjudul "the Research of Test on Stress-Strain Constitutive Relations of Straw Concrete" (2014), Wei Liu, Wie Xi dan Yilu Zhang melakukan pengujian tekan pada beton dengan inovasi penambahan jerami di dalamnya. Dengan metode eksperimen dan kontrol, hasil pengujian menunjukkan beton dengan campuran jerami kuat tekan dan modulus elastisitas yang 
hampir sama dengan beton yang tidak dicampur dengan jerami.

Penambahan tetes tebu atau molase pada batako membuat kuat tekan batako menurun. Batako tanpa jerami dan tanpa molase mempunyai kuat tekan sebesar 49,27 Kg/m ${ }^{2}$. Sementara batako tanpa jerami dengan molase sebesar $28,10 \mathrm{Kg} / \mathrm{m}^{2}$. Ada beberapa hal yang membuat hal tersebut dapat terjadi. Molase yang sudah dicampurkan ke dalam mortar membuat mortar menjadi lebih basah dan mempunyai waktu ikat yang lebih lama. Selain membuat mortar bisa lebih merekat dengan jerami, waktu ikat mortar yang lama berpengaruh pada lama pelepasan cetakan batako. Namun keterbatasan jumlah cetakan batako mengharuskan batako segera langsung dilepas dari cetakan. Hal ini dapat mempengaruhi kuat tekan batako dengan penambahan molase.

\section{Daya Serap Air (absorption) Batako}

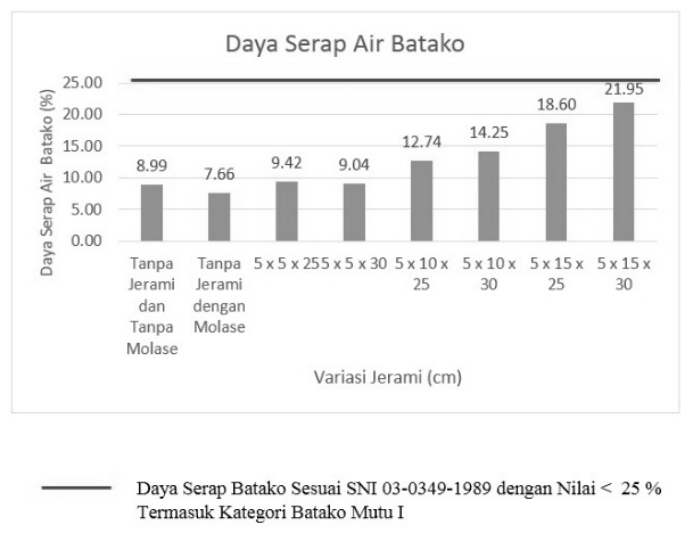

Gambar 6. Grafik Hasil Pengujian Daya Serap Air Batako

Berdasaran gambar 6 batako tanpa penambahan jerami dan tanpa molase mempunyai daya serap air sebesar 8,99\%. Batako tanpa penambahan jerami dengan molase mempunyai daya serap air $7,66 \%$. Sementara pada batako dengan penambahan jerami mempunyai grafik yang semakin meningkat. Batako dengan daya serap air paling tinggi terdapat pada variasi jerami berukuran (lebar: tinggi: panjang) $5 \mathrm{~cm}: 15 \mathrm{~cm}: 30 \mathrm{~cm}$ sebesar 21,95\%, Hal ini terjadi karena presentase jerami yang ada di dalam batako yang besar dibanding yang lainnya. Sementara batako dengan daya serap air terendah terdapat pada variasi jerami berukuran $5 \mathrm{~cm}: 5 \mathrm{~cm}: 30 \mathrm{~cm}$ sebesar $9,04 \%$.

Berdasarkan data pengujian daya serap air di atas menjukan bahwa batako dengan penambahan variasi jerami memenuhi syarat fisis bata beton dengan nilai daya serap air $<25$ $\%$ dan termasuk tingkat mutu bata beton pejal I sesuai SNI 03-03491989. Pada umumnya batako dengan ukuran dimensi jerami yang lebih besar mempunyai nilai daya serap air yang lebih besar dibandingkan ukuran dimensi jerami yang lebih kecil.

\section{SIMPULAN}

Penelitian ini menghasilkan kesimpulan bahwa:

1. Ada pengaruh positif penambahan variasi jerami padi dalam bentuk balok sebagai bahan pengisi pada batako terhadap berat isi batako.

2. Ada pengaruh negatif penambahan variasi jerami padi dalam bentuk balok sebagai bahan pengisi pada batako terhadap kuat tekan batako.

3. Ada pengaruh negatif penambahan variasi jerami padi dalam bentuk balok sebagai bahan pengisi pada batako terhadap daya serap air batako.

4. Hasil pengujian berat isi beton dari semua variasi jerami dalam bentuk balok termasuk kategori beton ringan $1000 \mathrm{~kg} / \mathrm{m}^{3}-2100 \mathrm{~kg} / \mathrm{m}^{3}$, sesuai dengan SNI 03-2834-2000.

5. Variasi optimal jerami padi dalam bentuk balok sebagai bahan pengisi 
batako yang menghasilkan kuat tekan batako maksimal sesuai SNI 03-0349-1989 terdapat pada pada variasi jerami dengan ukuran (lebar: tinggi: panjang) $5 \mathrm{~cm}: 5 \mathrm{~cm}: 25 \mathrm{~cm}$ yaitu sebesar $25,64 \mathrm{Kg} / \mathrm{cm}^{3}$.

6. Pada hasil uji daya serap air, dari berbagai variasi jerami padi dalam bentuk balok yang digunakan pada penelitian ini daya serap air (absorbsi) batako masih di bawah syarat penyerapan air rata-rata maksimal batako sesuai SNI 03-3491989 yaitu < 25\% termasuk dalam tingkat mutu bata beton pejal I. Hal tersebut dibuktikan dimana besarnya daya serap air (absorbtion) yang maksimal adalah penambahan jerami padi dengan ukuran (lebar: tinggi: panjang) $5 \mathrm{~cm}: 15 \mathrm{~cm}: 30 \mathrm{~cm}$, dengan nilai absorbtion yang maksimal yaitu sebesar 21,95\%. Dapat disimpulkan juga bahwa semakin besar dimensi jerami padi, maka semakin besar pula daya serap air (absorbtion).

\section{SARAN}

1. Penggunaan jerami padi sebaiknya menggunakan jerami padi dengan kualitas yang baik.

2. Pengepresan jerami padi sebaiknya menggunakan mesin pengepress untuk menghasilkan kualitas jerami cetak yang lebih baik.

3. Penggunaan lem perekat yang lebih kuat agar dihasilkan bentuk jerami cetak sesuai dengan bentuk dan ukuran yang diinginkan.

4. Penggunaan batako dengan bahan pengisi jerami hendaknya diperkenalkan kepada masyarakat karena dapat mengurangi limbah dibidang pertanian tanaman padi.

5. Pengepresan batako sebaiknya lebih lama, kurang lebih 24 jam.
6. Perlu adanya pengembangan penelitian lebih lanjut mengenai komposisi molase yang optimal sebagai bahan campuran batako isi jerami.

7. Perlu adanya pengembangan penelitian lebih lanjut untuk bahan tambahan selain jerami padi pada batako sehingga dihasilkan kuat tekan batako yang lebih baik.

\section{DAFTAR PUSTAKA}

Anonim. 1989. Standar Nasional Indonesia 03-349-1989: Bata Beton untuk Pasangan Dinding. Jakarta : BSN.

Anonim. 1990. Standar Nasional Indonesia 03-1968-1990: Agregat Halus dan Kasar, Metode Pengujian Analisis Saringan. Jakarta: BSN.

Anonim. 2000. Standar Nasional Indonesia 03-2834-2000: Berat Isi Beton. Jakarta : BSN.

Anonim. 2008. Standar Nasional Indonesia 1970-2008: Cara Uji Berat Jenis dan Penyerapan Air Agregat Halus. Jakarta: BSN.

Anggakusuma, Rizky. 2014. Kuat Tekan Batako dengan Penambahan Semen Merah dari Limbah Gerabah. Fakultas Teknik Universitas Sebebelas Maret. Surakarta.

Liu Wei, Wei Xi, and Yilu Zhang, 2014. The Research of Test On StressStrain Constitutive Relations of Straw Concrete. Applied Mechanics \& Materials. Jilin Jianzhu University, Changchun. China.

Prima, Ahmad dkk. 2013. Pemanfaatan Limbah Pabrik Gula (Tetes Tebu) Sebagai Bahan Tambah 
Dalam Campuran Beton.

Fakultas teknik. Universitas Sumatra Utara. Medan

Risvank. 2011. Disversifikasi Produk Pabrik Gula. www.risvank.com. 22 Juni 2017.

Tjokrodimuljo, Kardiyono. (2004). Teknologi Beton. Yogyakarta: Universitas Gajah Mada.

Wisnu, Wijanarko. 2008. Analisis Bahan Jerami Padi Dalam Bentuk Block Atau Kotak Sebagai Bahan Pengisi Batako. Fakultas Keguruan dan Ilmu Pendidikan. Universitas Sebelas Maret. Surakarta. 